New Zealand 1962 Meeting of the International Soil Science Society

The Massey University College at Palmerston North was the venue of the November 1962 meeting of the society. Forestry and agricultural interests were well represented in the contingent from Canada, whose numbers joined with some 300 other delegates from over 30 countries. Participants received an auspicious welcome from the Governor-General, the Prime Minister and other dignitaries, which was more than echoed by the hospitality of the New Zealand people throughout the length and breadth of their land.

The program comprised lectures, tours, exhibits and entertainment and had as its main theme advances and relationships between the two disciplines, soil fertility and plant nutrition, on the one hand, and soil genesis, classification and cartography on the other.

Over 100 papers-printed in full and circulated beforehand-were grouped into the four categories:

1. Soil Processes and Soil Fertility,

2. Soil Classification and Soil Fertility,

3. Soil Fertility and Land Use, and

4. Soil Science and Society.

These were further broken down into two-hour seminars during which one leading paper was presented with some five other more specialized studies.

The range of topics discussed and the global authorities participating rendered this a congress of interest to foresters everywhere, but giving it especial value was a group of 36 papers from 24 countries concerned with the survey and classification of soils for agriculture and forestry, and a purely forestry session devoted to methods for assessing forest site capacity. Mr. A. L. Poole, Director-General of the New Zealand Forest Service, chaired this session which included the following contributions:

P. J. Rennie, Canada. Methods of assessing forest site capacity.

H. D. Waring, Australia. Response by Pinus radiata to fertilizer nitrogen and its significance in the maintenance of forest soil fertility.

S. A. Wilde, U.S.A. Survey of soils supporting forest plantations in Wisconsin.

G. Manil, Belgium. Humus, forest capacity and forest site mapping. tion.

J. G. Iyer, India. Appraisal of tree planting stock on the basis of ordina-

E. Ehwald and D. Kopp, Germany. Forest site mapping in the German Democratic Republic.

G. M. Will, New Zealand. Assessment of forest site capacity in New Zealand.

S. V. Zonn, U.S.S.R. Principles of forest soil classification and methods for their investigation in the U.S.S.R.

Fortunately all papers-except a minority - and the discussions are published in full in the attractively bound Transactions of the Congress (available from the D.S.I.R., 125 Sydney Street W., Wellington, N.Z.) which, at a trifle over $\$ 11$ for 916 pages, represents excellent value for up-to-date reference and review material. No one interested in soil classification for agriculture and forestry purposes should be without it. 
The impeccably organized tours deserve a special word of credit. Smaller excursions included the active volcano region in the Tongariro National Park, the diversified research institutes of the Department of Scientific and Industrial Research, and the seat of government-Wellington-which has the largest wooden building in the Southern Hemisphere. Major excursions took members through the main agricultural and forest regions of each island. If the continued conversion of native forest to sheep pasture and the relict giant kauri stands in Traunson National Park were a sorry sight to a forester he could be more than heartened by the range of activities in forest practice and research currently under way. Although exotic softwood plantations are rapidly increasing importance, indigenous rain forest still accounts for some 40 percent of total production. The silviculture of rimu on the greypodzol gravels of Westland and the conversion of over-mature totara to exotic forest in central North Island were two typically challenging problems receiving intensive study. On the plantation side some of the most striking demonstrations included large-scale dune afforestation, thinning and pruning in relation to timber quality, aerial fertilizing and farm woodlots. In fact the interest in farm woodlots is widespread enough to support its own society-the New Zealand Farm Forestry Association-with its own highcalibre journal "Farm Forestry". Almost all the research specialities of the New Zealand Forest Service - silviculture, pathology, tree-breeding, utilization, etc.- - are centered at Rotorua under the direction of Dr. S. D. Richardson. Delegates were impressed by the degree of contact among workers, both within these forest disciplines and between forest science as a whole and other departments, such as the Soils Bureau (D.S.I.R.) and Agriculture.

The exhibits displayed included an excellent forestry panorama of the land forms, soils and forest types of Westland, a global collection of soil monoliths and relevant literature. Among the inexpensive texts invaluable to the forester visiting New Zealand may be mentioned the official 109-page Descriptive Atlas, the D.S.I.R. and Forest Research Institute Handbook, and Bulletin 12 and 13 of the Forest Service on indigenous and exotic forest trees. Of more general interest are Keith Sinclair's History (Pelican Books) and A. W. Reed's Dictionary of Maori Place Names.

There was little doubt that the outstanding success of the Conference and the practical achievements witnessed stemmed from the constructive cooperation of agriculturists, foresters and soil scientists under the skilful guidance of Mr. N. H. Taylor, Director of the Soils Bureau and President of the Conference. It is fitting that a country able to organize its soil survey service to the signal benefit of agriculture and forestry should take the first significant steps to synthesize the diverging disciplines of plant nutrition and soil classification.

P. J. RENNIE

\section{WALLACE ACHESON DELAHEY}

Forestry lost a long-time champion on January 20th, 1964, with the passing in Toronto of Wallace Acheson Delahey. Born in Balmoral, Manitoba, on December 26th, 1890, he was educated at public and high school in Pembroke, Ontario. He graduated from the Faculty of Forestry, University of 